\title{
PROFIL BERPIKIR KRITIS MAHASISWA PGMI DALAM MEMECAHKAN MASALAH MATEMATIKA DASAR
}

\author{
Sintha Sih Dewanti \\ UIN Sunan Kalijaga Yogyakarta \\ sintha_pmat@yahoo.com
}

\begin{abstract}
Abstrak
Tujuan penelitian ini adalah untuk mendeskripsikan profil berpikir kritis mahasiswa PGMI UIN Sunan Kalijaga Yogyakarta dalam memecahkan masalah matematika dasar. Pemecahan masalah merupakan proses mental tingkat tinggi dan memerlukan proses berpikir yang lebih kompleks termasuk berpikir kritis. Pemecahan masalah juga mempunyai hubungan timbal balik dengan berpikir kritis. Berpikir kritis pada penelitian ini mengacu pada berpikir kritis dengan kriteria FRISCO. Jenis penelitian ini adalah penelitian deskriptif dengan pendekatan kualitatif. Pada penelitian ini diambil 9 subjek penelitian, yaitu 3 subjek pada kemampuan matematika dasar tinggi, sedang, dan rendah. Pengumpulan data dilakukan dengan pemberian soal pemecahan masalah dan wawancara.

Ada 5 tipe masalah yang digunakan dalam soal pemecahan masalah yaitu: simple translation problem, complex translation problem, process problem, applied problem, dan puzzle problem. Profil berpikir kritis mahasiswa dalam memecahkan masalah matematika dasar menurut kriteria FRISCO pada setiap langkah pemecahan Polya sebagai berikut: a) Mahasiswa dengan KPM tinggi mengetahui fokus, alasan, situasi dan kejelasan dalam setiap tahap pemecahan masalah juga menjelaskan inferensinya pada setiap tahap pemecahan masalah Polya pada simple translation problem, complex translation problem, dan applied problem, tetapi belum dapat untuk 2 masalah lainnya; b) Mahasiswa dengan KPM sedang, mengetahui fokus, alasan, situasi dan kejelasan dalam setiap tahap pemecahan masalah juga menjelaskan inferensinya pada setiap tahap pemecahan masalah Polya pada simple translation problem dan applied problem tetapi belum dapat untuk 3 masalah lainnya; dan c) Mahasiswa dengan KPM rendah, mengetahui fokus, alasan, inferensi, situasi, klarifikasi dan memeriksa kembali pada setiap langkah pemecahan masalah Polya pada masalah simple translation problem, dan belum dapat pada puzzle problem, sedangkan untuk 3 masalah lainnya mengetahui fokus dan alasan hanya sampai pada langkah melaksanakan strategi, tetapi belum dapat mengetahui inferensinya.
\end{abstract}

Kata kunci: berpikir kritis, pemecahan masalah, kemampuan matematika dasar

\begin{abstract}
The purpose of this research is to describe the critical thinking profile of PGMI UIN Sunan Kalijaga Yogyakarta students in solving basic mathematics problems. Problem solving is a high level mental process and requires a more complex thinking process including critical thinking. Problem solving also has a reciprocal relationship with critical thinking. Critical thinking in this study refers to critical thinking with the FRISCO criteria. The type of this research is descriptive research with qualitative approach. In this study, 9 subjects taken, that is 3 subject to the ability of high-basic mathematic, medium, and low. Data was collected by way of tests and interviews.

There are 5 types of problems used in problem solving tests: simple translation problem, complex translation problem, problem process, applied problem, and puzzle problem. The profile of critical thinking of students in solving basic mathematics problems according to FRISCO criteria at each polya solving step as follows: a)
\end{abstract}


Students with high problem solving abilitys know the focus, reason, situation and clarity in every problem solving step also explain the inferences at each stage of solving Polya problem on simple translation problem, complex translation problem, and applied problem, but not yet for 2 other problems; b) Students with medium problem solving abilitys know the focus, reason, situation and clarity in each stage of problem solving also explain the inferences at each stage of polya problem solving on simple translation problem and applied problem but not yet for the other 3 problems; and c) Students with low problem solving abilitys know the focus, reason, inference, situation, clarification and re-examine each step Polya problem solving on the problem of simple translation problem, and not yet in the puzzle problem, while for 3 other problems know the focus and reason only to the step of implementing the strategy, but not yet know the inferences.

Keywords: critical thinking, problem solving, basic math ability

Sitasi: Dewanti, S. S. 2018. Profil Berpikir Kritis Mahasiswa PGMI dalam Memecahkan Masalah Matematika Dasar. Matematika dan Pembelajaran, 6(1), 11-22.

\section{PENDAHULUAN}

Masalah merupakan hal yang biasa ditemukan dalam proses pembelajaran. Adanya permasalahan merupakan suatu indikasi bahwa seorang individu mengalami kesulitan dalam menyelesaikan suatu hal. Suatu pertanyaan akan menjadi masalah hanya jika pertanyaan itu menunjukkan adanya tantangan yang tidak dapat dipecahkan dengan suatu prosedur rutin yang sudah diketahui oleh penjawab pertanyaan. Suatu masalah bagi siswa A belum tentu menjadi masalah bagi siswa B, jika siswa B sudah mengetahui prosedur untuk menyelesaikannya, sementara siswa A belum pernah mengetahui prosedur untuk menyelesaikannya.

Lenchner (1983) menyatakan bahwa pada intinya setiap penugasan kepada siswa dalam belajar matematika dapat dikelompokkan ke dalam dua hal, yaitu sebagai latihan (drill exercise) dan sebagai masalah (problem) untuk dipecahkan. Latihan merupakan tugas yang cara atau langkah atau prosedur penyelesaiannya sudah dipelajari atau diketahui siswa. Pada umumnya latihan dapat diselesaikan dengan menerapkan satu atau lebih langkah yang sebelumnya sudah dipelajari siswa.

Menurut Suherman (2003) suatu masalah biasanya memuat suatu situasi yang mendorong seseorang untuk menyelesaikannya, tetapi tidak tahu secara langsung apa yang harus dikerjakan untuk menyelesaikannya. Masalah bukanlah persoalan yang hanya dengan memasukkan suatu nilai ke dalam formula tertentu, seseorang dapat menyelesaikannya dengan benar. Masalah lebih kompleks daripada latihan, sehingga metode untuk menyelesaikan masalah tidak langsung tampak. Oleh karena itu, dalam pemecahan masalah melibatkan proses mental tingkat tinggi dan diperlukan proses berpikir yang lebih kompleks termasuk berpikir kritis.

Krulik \& Rudnick (1989) mendefinisikan berpikir kritis sebagai berpikir yang menguji, menghubungkan, dan mengevaluasi semua aspek dari situasi masalah. Termasuk di dalam berpikir kritis adalah mengelompokkan, mengorganisasikan, mengingat dan menganalisis informasi. Sejalan dengan itu, Norris \& Ennis (Alec Fisher, 2001) menyatakan berpikir kritis adalah berpikir yang beralasan dan reflektif yang fokus untuk memutuskan apa yang dapat dipercaya dan apa yang tidak dapat dipercaya. 
Berpikir kritis memerlukan kemampuan membaca, memahami dan mengidentifikasi masalah serta kemampuan mengklasifikasi dan membandingkan, sehingga dapat menggambarkan kesimpulan dengan lebih baik dari yang diberikan, serta dapat menentukan ketidakkonsistenan dan kontradiksi dari informasi tersebut. Tidak semua informasi yang diterima dapat dijadikan pengetahuan yang diyakini kebenarannya untuk dijadikan panduan dalam tindakan. Demikian halnya dengan informasi yang dihasilkan, tidak selalu merupakan informasi yang benar. Keputusan atau kesimpulan yang dilakukan dengan berpikir kritis merupakan informasi terbaik setelah melalui pengkajian dari berbagai sumber informasi, termasuk mengkaji kesimpulan yang dihasilkan dengan memberikan bukti-bukti yang mendukung.

Pemecahan masalah mempunyai hubungan timbal balik dengan berpikir kritis. Melalui belajar memecahkan masalah dapat dibentuk antara lain cara berpikir secara analitik, logis, dan deduktif yang merupakan komponen berpikir kritis. Belajar dengan pemecahan masalah akan melatih siswa terampil dalam berpikir. Berpikir kritis diperlukan dalam pemecahan masalah karena dalam memecahkan masalah berpikir kritis memberikan arahan yang tepat dalam berpikir dan bekerja, serta membantu menemukan keterkaitan faktor yang satu dengan yang lainnya secara lebih akurat. Dalam pembelajaran matematika siswa yang kritis akan terbantu dalam memecahkan masalah matematika. Sebaliknya seorang siswa yang biasa menyelesaikan masalah matematika akan cenderung berpikir kritis. Berdasarkan uraian di atas, kemampuan pemecahan masalah dan berpikir kritis sangat diperlukan terutama bagi mahasiswa PGMI sebagai calon guru MI. Karena adanya keterkaitan antara pemecahan masalah dengan berpikir kritis, maka penulis mengadakan penelitian yang bertujuan untuk mendeskripsikan profil berpikir kritis mahasiswa PGMI dalam memecahkan masalah matematika dasar.

\section{KAJIAN TEORI}

\section{Berpikir Kritis}

Gega (1977) mengemukakan bahwa seseorang yang berpikir kritis akan menggunakan bukti untuk mengukur kebenaran kesimpulan, serta dapat menunjukkan pendapat yang terkadang kontradiktif, bahkan mau mengubah pendapatnya jika ternyata ada bukti lebih kuat yang bertentangan dengan pendapatnya. Berpikir kritis meliputi dua langkah besar yakni melakukan proses penalaran yang diikuti dengan pengambilan keputusan atau pemecahan masalah. Tanpa kemampuan yang memadai dalam hal penalaran, maka seseorang tidak dapat melakukan proses berpikir kritis secara benar. Dapat disimpulkan bahwa berpikir kritis adalah kegiatan berpikir yang mendalam, komprehensif, argumentatif-logis, dan evaluatif.

Kemampuan berpikir kritis sangat penting dimiliki oleh setiap individu karena dengan berpikir kritis seseorang akan lebih bijak dalam menghadapi segala kejadian dalam kehidupannya. Tujuan dari berpikir kritis adalah untuk mencapai pemahaman yang mendalam (Johnson, 2007). Dengan pemahaman yang mendalam tersebut seseorang akan mampu mengungkap makna di balik informasi yang diperoleh sehingga dapat menemukan kebenaran di tengah banyaknya informasi yang tersedia.

Untuk menilai berpikir kritis seseorang, Ennis (1995) memperkenalkan 6 kriteria berpikir 
kritis (yang disingkat FRISCO) meliputi:

a. focus yaitu mengetahui poin utama sesuatu yang sedang dilakukan atau dihadapi, biasanya berupa simpulan,

b. reason yaitu memberikan alasan-alasan yang mendukung kesimpulan yang diambil,

c. inference adalah proses penarikan kesimpulan yang masuk akal, yaitu langkah-langkah dari alasan menuju kesimpulan,

d. situation yaitu mengungkap faktor-faktor penting yang perlu dipertimbangkan dalam menilai atau memutuskan,

e. clarity yaitu menjelaskan istilah-istilah yang digunakan dalam berpendapat, dan

f. overview adalah mengecek semua tindakan yang telah dilakukan apakah masuk akal.

\section{Pemecahan Massalah}

Menurut Holmes (1995) terdapat 2 kelompok masalah dalam pembelajaran matematika yaitu masalah rutin dan masalah non rutin. Masalah rutin dapat dipecahkan dengan metode yang sudah ada. Masalah rutin sering disebut sebagai masalah penerjemahan karena deskripsi situasi dapat diterjemahkan dari kata-kata menjadi simbol-simbol. Masalah rutin dapat membutuhkan satu, dua atau lebih langkah pemecahan. Charles (Holmes, 1995) menyatakan bahwa masalah rutin memiliki aspek penting dalam kurikulum, karena hidup ini penuh dengan masalah rutin. Oleh karena itu tujuan pembelajaran matematika yang diprioritaskan terlebih dahulu adalah siswa dapat memecahkan masalah rutin.

Menurut Kouba et.al (Holmes, 1995) masalah non rutin kadang mengarah kepada masalah proses. Masalah non rutin membutuhkan lebih dari sekadar penerjemahan masalah menjadi kalimat matematika dan penggunaan prosedur yang sudah diketahui. Masalah non rutin mengharuskan pemecah masalah untuk membuat sendiri metode pemecahannya, kemudian merencanakan dengan seksama untuk memecahkan masalah tersebut. Strategistrategi seperti menggambar, menebak dan melakukan cek, membuat tabel atau urutan kadang perlu dilakukan.

Strategi umum memecahkan masalah yang terkenal adalah strategi Polya (Polya, 1973), yaitu 4 langkah rencana pemecahan masalah sebagai berikut.

a. Langkah 1: Memahami Masalah

Langkah ini sangat menentukan kesuksesan memperoleh solusi masalah. Langkah ini melibatkan pendalaman situasi masalah, melakukan pemilahan fakta-fakta, menentukan hubungan diantara fakta-fakta dan membuat formulasi pertanyaan masalah. Setiap masalah yang tertulis, bahkan yang paling mudah sekalipun harus dibaca berulang kali dan informasi yang terdapat dalam masalah dipelajari dengan seksama. Biasanya siswa harus menyatakan kembali masalah dalam bahasanya sendiri. Membayangkan situasi masalah dalam pikiran juga sangat membantu untuk memahami struktur masalah.

b. Langkah 2: Membuat rencana pemecahan masalah

Langkah ini perlu dilakukan dengan percaya diri ketika masalah sudah dapat dipahami. Rencana solusi dibangun dengan mempertimbangkan struktur masalah dan pertanyaan yang harus dijawab. Untuk masalah rutin dengan tugas menulis kalimat matematika terbuka, maka perlu dilakukan penerjemahan masalah menjadi bahasa matematika.

c. Langkah 3: Melaksanakan rencana pemecahan masalah

Untuk mencari solusi yang tepat, rencana yang sudah dibuat dalam langkah 2 harus 
dilaksanakan dengan hati-hati. Untuk memulai, kadang perlu membuat estimasi solusi. Diagram, tabel atau urutan dibangun secara seksama sehingga si pemecah masalah tidak akan bingung. Jika muncul ketidakkonsistenan ketika melaksanakan rencana, maka proses harus ditelaah ulang untuk mencari sumber kesulitannya.

d. Langkah 4: Memeriksa (mengecek) kembali

Selama langkah ini berlangsung, solusi masalah harus dipertimbangkan. Perhitungan harus dicek kembali. Melakukan pengecekan ke belakang akan melibatkan penentuan ketepatan perhitungan dengan cara menghitung ulang. Jika kita membuat estimasi atau perkiraan, maka bandingkan dengan hasilnya. Bagian penting dari langkah ini adalah membuat perluasan masalah yang melibatkan pencarian alternatif pemecahan masalah.

\section{Berpikir Kritis dalam Memecahkan Masalah}

Berpikir kritis diperlukan dalam pemecahan masalah karena dengan berpikir kritis dapat memberikan arahan yang tepat dalam berpikir dan bekerja, serta membantu menemukan keterkaitan faktor yang satu dengan yang lainnya secara lebih akurat. Dalam pembelajaran matematika siswa yang kritis akan terbantu dalam memecahkan masalah matematika. Kriteria FRISCO pada setiap langkah pemecahan Polya disajikan dalam tabel 1 berikut.

Tabel 1. Kriteria FRISCO pada setiap langkah pemecahan Polya

\begin{tabular}{|c|c|c|c|c|}
\hline Kriteria & $\begin{array}{c}\text { Memahami } \\
\text { Masalah }\end{array}$ & $\begin{array}{l}\text { Membuat } \\
\text { Rencana }\end{array}$ & $\begin{array}{c}\text { Melaksanakan } \\
\text { Rencana }\end{array}$ & $\begin{array}{c}\text { Memeriksa } \\
\text { Kembali }\end{array}$ \\
\hline Focus & $\begin{array}{l}\text { Membangun makna } \\
\text { tentang masalah } \\
\text { apa yang akan } \\
\text { dipecahkan dengan } \\
\text { cara merumuskan } \\
\text { kembali masalah } \\
\text { dengan model } \\
\text { matematika, } \\
\text { gambar, grafik, dll }\end{array}$ & $\begin{array}{l}\text { Memutuskan strategi } \\
\text { apa yang akan } \\
\text { dipakai untuk } \\
\text { memecahkan } \\
\text { masalah }\end{array}$ & $\begin{array}{l}\text { Langkah-langkah } \\
\text { penerapan } \\
\text { strategi yang } \\
\text { telah dipilih }\end{array}$ & $\begin{array}{l}\text { Keputusan untuk } \\
\text { memeriksa } \\
\text { jawaban yang } \\
\text { diperoleh }\end{array}$ \\
\hline Reason & $\begin{array}{l}\text { Memberikan alasan } \\
\text { terhadap hasil } \\
\text { rumusan masalah } \\
\text { yang telah } \\
\text { dibangun }\end{array}$ & $\begin{array}{l}\text { Memberikan alasan } \\
\text { mengapa } \\
\text { menggunakan } \\
\text { strategi tersebut }\end{array}$ & $\begin{array}{l}\text { Memberikan } \\
\text { alasan langkah } \\
\text { penerapannya }\end{array}$ & $\begin{array}{l}\text { Memberikan } \\
\text { alasan mengapa } \\
\text { memeriksa } \\
\text { jawaban } \\
\text { tersebut }\end{array}$ \\
\hline Inference & $\begin{array}{l}\text { Proses penarikan } \\
\text { kesimpulan yang } \\
\text { masuk akal } \\
\text { menurut } \\
\text { penyelidikan (tidak } \\
\text { bertentangan } \\
\text { dengan data yang } \\
\text { ada) dari rangkaian } \\
\text { alasan yang }\end{array}$ & $\begin{array}{l}\text { Proses penarikan } \\
\text { kesimpulan yang } \\
\text { masuk akal dari } \\
\text { rangkaian alasan } \\
\text { menggunakan } \\
\text { strategi tertentu } \\
\text { sampai pada } \\
\text { keputusan untuk } \\
\text { menggunakan }\end{array}$ & $\begin{array}{l}\text { Proses penarikan } \\
\text { kesimpulan yang } \\
\text { masuk akal } \\
\text { menurut } \\
\text { penyelidikan dari } \\
\text { rangkaian alasan } \\
\text { sampai keputusan } \\
\text { langkah-langkah } \\
\text { penerapannya. }\end{array}$ & $\begin{array}{l}\text { Proses } \\
\text { penarikan } \\
\text { kesimpulan } \\
\text { yang masuk } \\
\text { akal dari } \\
\text { rangkaian alasan } \\
\text { sampai } \\
\text { keputusan untuk } \\
\text { memeriksa }\end{array}$ \\
\hline
\end{tabular}


Dewanti, S. S. 2018. Profil Berpikir Kritis Mahasiswa PGMI... Matematika dan Pembelajaran, 6(1), 16 of 22

\begin{tabular}{|c|c|c|c|c|}
\hline Kriteria & $\begin{array}{c}\text { Memahami } \\
\text { Masalah }\end{array}$ & $\begin{array}{l}\text { Membuat } \\
\text { Rencana }\end{array}$ & $\begin{array}{c}\text { Melaksanakan } \\
\text { Rencana }\end{array}$ & $\begin{array}{c}\text { Memeriksa } \\
\text { Kembali }\end{array}$ \\
\hline & $\begin{array}{l}\text { dikemukakan } \\
\text { sampai pada } \\
\text { penarikan } \\
\text { kesimpulan. }\end{array}$ & strategi tersebut. & & $\begin{array}{l}\text { kembali } \\
\text { jawaban. }\end{array}$ \\
\hline Situation & $\begin{array}{l}\text { Mengetahui apa } \\
\text { yang diketahui dan } \\
\text { apa yang } \\
\text { ditanyakan dalam } \\
\text { soal }\end{array}$ & $\begin{array}{l}\text { Mengetahui hal-hal } \\
\text { penting yang perlu } \\
\text { diperhatikan dalam } \\
\text { membuat rencana } \\
\text { yaitu mengetahui } \\
\text { apa yang harus } \\
\text { dilakukan dalam } \\
\text { menerapkan } \\
\text { strategi. }\end{array}$ & $\begin{array}{l}\text { Mengetahui hal- } \\
\text { hal penting yang } \\
\text { perlu diperhatikan } \\
\text { dalam langkah- } \\
\text { langkah } \\
\text { penerapan } \\
\text { strategi. }\end{array}$ & $\begin{array}{l}\text { Mengetahui hal- } \\
\text { hal penting yang } \\
\text { perlu } \\
\text { diperhatikan } \\
\text { dalam } \\
\text { memeriksa } \\
\text { jawaban yang } \\
\text { diperoleh. }\end{array}$ \\
\hline Clarity & $\begin{array}{l}\text { Menjelaskan } \\
\text { istilah-istilah yang } \\
\text { digunakan } \\
\text { (dikroscek melalui } \\
\text { wawancara) }\end{array}$ & $\begin{array}{l}\text { Menjelaskan } \\
\text { istilah-istilah yang } \\
\text { digunakan } \\
\text { (dikroscek melalui } \\
\text { wawancara) }\end{array}$ & $\begin{array}{l}\text { Menjelaskan } \\
\text { istilah-istilah yang } \\
\text { digunakan } \\
\text { (dikroscek } \\
\text { melalui } \\
\text { wawancara) }\end{array}$ & $\begin{array}{l}\text { Menjelaskan } \\
\text { istilah-istilah } \\
\text { yang digunakan } \\
\text { (dikroscek } \\
\text { melalui } \\
\text { wawancara) }\end{array}$ \\
\hline Overview & $\begin{array}{l}\text { Mengecek semua } \\
\text { hal yang telah } \\
\text { dilakukan dari } \\
\text { alasan yang } \\
\text { diberikan sampai } \\
\text { pada kesimpulan } \\
\text { apakah semuanya } \\
\text { masuk akal }\end{array}$ & $\begin{array}{l}\text { Mengecek semua } \\
\text { hal yang telah } \\
\text { dilakukan dari } \\
\text { alasan yang } \\
\text { diberikan sampai } \\
\text { pada keputusan } \\
\text { tentang strategi } \\
\text { yang akan } \\
\text { digunakan apakah } \\
\text { semuanya masuk } \\
\text { akal }\end{array}$ & $\begin{array}{l}\text { Mengecek semua } \\
\text { hal yang telah } \\
\text { dilakukan dari } \\
\text { alasan yang } \\
\text { diberikan sampai } \\
\text { pada langkah- } \\
\text { langkah } \\
\text { penerapan strategi } \\
\text { apakah semuanya } \\
\text { masuk akal }\end{array}$ & $\begin{array}{l}\text { Mengecek } \\
\text { semua hal yang } \\
\text { telah dilakukan } \\
\text { dan alasan yang } \\
\text { diberikan } \\
\text { sampai pada } \\
\text { kesimpulan } \\
\text { untuk } \\
\text { memeriksa } \\
\text { jawaban apakah } \\
\text { semuanya } \\
\text { masuk akal. }\end{array}$ \\
\hline
\end{tabular}

\section{METODE}

Penelitian ini merupakan penelitian deskriptif dengan pendekatan kualitatif. Subjek penelitian ini adalah mahasiswa Program Studi PGMI Fakultas Ilmu Tarbiyah dan Keguruan UIN Sunan Kalijaga Yogyakarta yang mengambil mata kuliah matematika dasar pada semester genap Tahun Akademik 2017/2018. Subjek diambil dengan 3 tingkat kemampuan pemecahan masalah berbeda yang dapat dilihat dari Skor Kemampuan Pemecahan Masalah (SKPM), yaitu: 1) tiga mahasiswa dengan KPM tinggi (SKPM > 80); 2) tiga mahasiswa dengan KPM sedang $(60 \leq \mathrm{SKPM} \leq 80)$; dan 3$)$ tiga mahasiswa dengan KPM rendah (SKPM < 60). Subjek yang dipilih harus dapat mengomunikasikan hasil pemikirannya. Teknik pengambilan data dengan pemberian soal pemecahan masalah dan 
wawancara berkaitan dengan hasil pekerjaan soal pemecahan masalah. Sebelum dianalisis, perlu diperiksa keabsahan data dengan menggunakan triangulasi waktu. Data yang valid kemudian dianalisis dan disimpulkan. Dari kesimpulan tersebut akan diperoleh deskripsi profil berpikir kritis mahasiswa PGMI dalam memecahkan masalah matematika dasar. Proses analisis data berpedoman pada Tabel 1 Kriteria FRISCO pada setiap langkah pemecahan Polya.

\section{HASIL DAN PEMBAHASAN}

Materi soal tes kemampuan pemecahan masalah meliputi pola, bilangan, geometri bangun datar, dan geometri bangun ruang. Ada 5 tipe masalah yang digunakan dalam soal pemecahan masalah yaitu.

1. Masalah penerjemahan sederhana (simple translation problem)

Penggunaan masalah dalam pembelajaran dimaksudkan untuk memberi pengalaman kepada mahasiswa menerjemahkan situasi dunia nyata ke dalam pengalaman matematis.

2. Masalah penerjemahan kompleks (complex translation problem)

Sebenarnya masalah ini mirip dengan masalah penerjemahan yang sederhana, namun didalamnya menuntut lebih dari satu kali penerjemahan dan ada lebih dari satu operasi hitung yang terlibat.

3. Masalah proses (process problem)

Penggunaan masalah tersebut dalam pembelajaran dimaksudkan untuk memberi kesempatan kepada mahasiswa mengungkapkan proses yang terjadi dalam pikirannya. Mahasiswa dilatih untuk mengembangkan strategi umum dalam memahami, merencanakan, dan memecahkan masalah, sekaligus mengevaluasi hasilnya.

4. Masalah penerapan (applied problem)

Penggunaan masalah tersebut dalam pembelajaran dimaksudkan untuk memberi kesempatan kepada mahasiswa mengeluarkan berbagai keterampilan, proses, konsep dan fakta untuk memecahkan masalah nyata (kontekstual). Masalah ini akan menyadarkan mahasiswa pada nilai dan kegunaan matematika dalam kehidupan sehari-hari.

5. Masalah puzzle (puzzle problem)

Penggunaan masalah tersebut dalam pembelajaran dimaksudkan untuk memberi kesempatan kepada mahasiswa mendapatkan pengayaan matematika yang bersifat rekreasi (recreational mathematics). Mahasiswa menemukan suatu penyelesaian yang terkadang fleksibel namun di luar perkiraan (memandang suatu masalah dari berbagai sudut pandang).

Skor pemecahan masalah dari 9 mahasiswa dengan skor maksimal tiap butirnya adalah 20 disajikan dalam tabel berikut.

Tabel 2. Skor Pemecahan Masalah

\begin{tabular}{|c|c|c|c|c|c|c|c|}
\hline \multirow[b]{2}{*}{ KPM } & \multirow[b]{2}{*}{$\begin{array}{l}\text { Kode } \\
\text { Mhsw }\end{array}$} & \multicolumn{5}{|c|}{ Masalah } & \multirow[b]{2}{*}{$\begin{array}{c}\text { Jumlah } \\
\text { Skor }\end{array}$} \\
\hline & & $\begin{array}{c}\text { penerjemahan } \\
\text { sederhana }\end{array}$ & $\begin{array}{c}\text { penerjemahan } \\
\text { kompleks }\end{array}$ & proses & penerapan & puzzle & \\
\hline \multirow{2}{*}{$\stackrel{200}{E} \cdot 50$} & $\mathbf{T}_{1}$ & 20 & 16 & 16 & 20 & 8 & 80 \\
\hline & $\mathbf{T}_{2}$ & 20 & 20 & 16 & 20 & 12 & 88 \\
\hline
\end{tabular}


Dewanti, S. S. 2018. Profil Berpikir Kritis Mahasiswa PGMI... Matematika dan Pembelajaran, 6(1), 18 of 22

\begin{tabular}{|c|c|c|c|c|c|c|c|}
\hline & $\mathbf{T}_{\mathbf{3}}$ & 20 & 20 & 12 & 20 & 12 & 84 \\
\hline \multirow{3}{*}{ 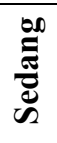 } & $\mathbf{S}_{1}$ & 20 & 8 & 16 & 20 & 10 & 74 \\
\hline & $\mathbf{S}_{2}$ & 20 & 16 & 8 & 16 & 6 & 66 \\
\hline & $\mathbf{S}_{\mathbf{3}}$ & 20 & 12 & 8 & 20 & 6 & 66 \\
\hline \multirow{3}{*}{ 竭 } & $\mathbf{R}_{1}$ & 20 & 6 & 8 & 20 & 0 & 54 \\
\hline & $\mathbf{R}_{2}$ & 16 & 4 & 4 & 12 & 0 & 36 \\
\hline & $\mathbf{R}_{\mathbf{3}}$ & 16 & 6 & 4 & 8 & 0 & 34 \\
\hline
\end{tabular}

Keterangan: KPM = Kemampuan Pemecahan Masalah

Berdasarkan data tabel 2 tampak bahwa kemampuan pemecahan masalah mahasiswa paling tinggi pada pemecahan masalah penerjemahan sederhana, kemudian pemecahan masalah penerapan, pemecahan masalah penerjemahan kompleks, pemecahan masalah proses, dan kemampuan paling rendah pada pemecahan masalah puzzle.

Banyak strategi berbeda yang dilakukan dalam penyelesaian masalah. Untuk masalah rutin, strategi yang sering dipakai adalah menulis kalimat matematika terbuka. Strategi menulis kalimat matematika terbuka ini melibatkan pemahaman tentang hubungan dan pertanyaan dalam masalah serta menerjemahkannya ke dalam bahasa matematika. Beberapa mahasiswa menggunakan masalah yang lebih sederhana atau memanggil kembali masalah yang hampir sama sebelum menulis kalimat matematika terbuka untuk masalah rutin.

Terdapat beberapa strategi yang digunakan mahasiswa dalam menyelesaikan masalah non rutin, yaitu:

1. Act It Out; Mahasiswa dapat memahami masalah dengan melakukan permainan peran. Tindakan akan membantu mahasiswa dalam merepresentasikan struktur masalah yang berarti baginya.

2. Menggambar diagram; Strategi menggambar diagram melibatkan situasi masalah dengan membuat sketsa atau diagram. Ini adalah salah satu strategi yang penting dalam pemecahan masalah karena penggunaannya yang luas dalam masalah non rutin. Hembree (Holmes, 1995) menyimpulkan dari analisis terhadap 487 pemecahan masalah, strategi membuat diagram paling menguntungkan dibandingkan strategi lain.

3. Menebak dan mengecek atau "Trial and Error"; Strategi ini hampir selalu tepat untuk masalah yang melibatkan proses coba dan gagal (trial and error) dan masalah yang melibatkan alasan dalam penentuan jawabannya. Strategi ini membantu mahasiswa untuk menyadari kenyataan bahwa tebakan yang bagus dalam matematika mendapat tempat dan tidak harus dihindari. Mahasiswa akan belajar bahwa dalam beberapa masalah, tebakan yang bagus adalah cara untuk memulai membuat rencana pemecahan masalah karena tidak ada cara yang lain. Mahasiswa akan menemukan bahwa strategi menebak dan mengecek berbeda dari perkiraan dalam memecahkan masalah. Perkiraan membantu untuk menilai solusi yang ditemukan dengan menggunakan strategi perkiraan.

4. Bekerja mundur atau ke arah belakang; Mahasiswa perlu memahami operasi balik untuk memecahkan masalah dengan strategi "bekerja mundur". Misalnya bilangan terakhir dari sebuah masalah sudah diketahui namun bilangan awalnya belum diketahui, maka strategi yang dilakukan adalah membalik operasi untuk menemukan bilangan awalnya. 
5. Membuat daftar yang terorganisir; Sebuah daftar dibuat untuk memastikan semua kemungkinan perhitungan dilibatkan dan tidak ada data yang dimasukkan secara berulang. Menghitung sering digunakan untuk menggambarkan hasil akhir. Daftar digunakan sebagai perbandingan atau pola penemuan untuk menentukan satu atau lebih jawabannya.

6. Membuat tabel; Tabel terdiri atas baris dan kolom yang menunjukkan hubungan variabel dalam sebuah masalah. Data yang dimasukkan dalam tabel menunjukkan urutan yang berulang, dan pemahaman terhadap input data dapat menjadi awal untuk memecahkan masalah.

7. Menemukan pola; Penggunaan pola dominan dalam pembelajaran matematika. Pola dapat memudahkan dalam merumuskan aturan dan memprediksi hasil. Masalah yang pemecahannya dengan mencari pola sering membutuhkan pembuatan tabel atau daftar, menggunakan strategi "menebak dan mengecek". Beberapa masalah dalam bagian "membuat tabel" dan "menebak dan mengecek" memerlukan pencarian pola.

8. Menggunakan masalah yang lebih sederhana; Masalah dengan bilangan yang besar atau pecahan seringkali terlihat sulit. Menyubstitusikan bilangan bulat yang kecil biasanya akan memudahkan pemecahan masalah. Pecahkan masalah dengan bilangan yang disubstitusikan tersebut, dan kemudian kembalikan ke masalah aslinya. Cara tersebut merupakan sebuah strategi pemecahan masalah dan dapat membuat mahasiswa lebih percaya diri dalam memecahkannya. Masalah-masalah rutin seringkali menjadi lebih sederhana dengan strategi ini.

9. Memanggil kembali masalah yang hampir sama; Kebanyakan masalah memiliki struktur yang sama dan dipecahkan melalui cara yang sama. Seringkali bahasa masalah cukup untuk mengingatkan kembali pemecahan suatu masalah dengan masalah sebelumnya yang mirip.

10. Menggunakan logika; Masalah logika membutuhkan pengandaian "jika..., maka". Strategi ini untuk menentukan apa yang diketahui dan memantapkan relasi atau hubungan lain. Memecahkan masalah logika akan melibatkan kemungkinankemungkinan dengan penalaran. Masalah logika yang berupa aturan seringkali membutuhkan diagram.

Dalam pemecahan masalah, selain strategi pemecahan masalah yang harus dikuasai, juga diperlukan kemampuan berpikir kritis. Menurut Ennis (1995), berpikir kritis adalah berpikir secara beralasan dan reflektif dengan menekankan pada pembuatan keputusan tentang apa yang harus dipercayai atau dilakukan. Ada 5 aktivitas kritis mahasiswa dalam memecahkan masalah yaitu:

1. mampu merumuskan pokok-pokok permasalahan;

2. mampu mengungkap fakta yang dibutuhkan dalam menyelesaikan suatu masalah;

3. mampu memilih argumen logis, relevan, dan akurat;

4. mampu mendeteksi bias berdasarkan sudut pandang yang berbeda; dan

5. mampu menentukan akibat dari suatu pernyataan yang diambil sebagai suatu keputusan.

Berdasarkan hasil wawancara mendalam dari setiap penyelesaian soal kepada subjek, diperoleh profil berpikir kritis mahasiswa PGMI menurut kriteria FRISCO pada setiap langkah pemecahan Polya. Berikut ini hasil analisisnya. 
1. Mahasiswa dengan KPM tinggi mengetahui fokus, alasan, situasi dan kejelasan dalam setiap tahap pemecahan masalah juga menjelaskan inferensinya pada setiap tahap pemecahan masalah Polya pada simple translation problem, complex translation problem, dan applied problem. Pada process problem, mahasiswa tidak melakukan pengecekan kembali. Untuk puzzle problem, mahasiswa tidak dapat memberikan alasan mengapa menggunakan strategi tersebut.

2. Mahasiswa dengan KPM sedang, mengetahui fokus, alasan, situasi dan kejelasan dalam setiap tahap pemecahan masalah juga menjelaskan inferensinya pada setiap tahap pemecahan masalah Polya pada simple translation problem dan applied problem. Pada complex translation problem dan process problem, mahasiswa tidak bisa menjelaskan proses penarikan kesimpulan secara masuk akal menurut penyelidikan dari rangkaian alasan sampai keputusan langkah-langkah penerapannya. Mahasiswa tidak dapat menjelaskan situasi pada saat ia melaksanakan rencana. Mahasiswa tidak melakukan langkah memeriksa kembali, sehingga profil berpikir kritisnya pada langkah ini tidak dapat dideskripsikan. Pada puzzle problem mahasiswa tidak dapat mengetahui hal-hal penting yang perlu diperhatikan dalam langkahlangkah penerapan strategi.

3. Mahasiswa dengan KPM rendah, mengetahui fokus, alasan, inferensi, situasi, klarifikasi dan memeriksa kembali pada setiap langkah pemecahan masalah Polya pada masalah simple translation problem. Untuk applied problem, mahasiswa juga mampu mengetahui seperti pada simple translation problem, namun inferensi hanya mampu dijelaskan pada tahap melaksanakan rencana dan memeriksa kembali, kejelasan hanya diberikan pada saat membuat rencana dan memeriksa kembali. Sementara situasi dijelaskan pada setiap langkah pemecahan masalah, kecuali pada langkah melaksanakan rencana. Pada complex translation problem dan process problem, mahasiswa tidak dapat memberikan alasan pada setiap langkah pemecahan masalah. Untuk puzzle problem, mahasiswa tidak dapat membangun makna tentang masalah apa yang akan dipecahkan. Mahasiswa tidak dapat merumuskan kembali masalah dalam model matematika, gambar, grafik, dll.

Jika ditinjau dari tingkatan berpikir kritis (Elder dan Paul, 2010), maka mahasiswa yang mempunyai KPM tinggi pada tingkatan advanced thinking dan accomplished thinking. Pada tingkatan berpikir lanjut (advanced thinking), mahasiswa aktif menganalisis pikirannya, memiliki pengetahuan yang penting tentang masalah pada tingkat berpikir yang mendalam. Namun mahasiswa belum mampu berpikir pada tingkat yang lebih tinggi secara konsisten pada semua dimensi kehidupannya. Pada tingkatan berpikir yang unggul (accomplished thinking), mahasiswa menginnternalisasi kemampuan dasar berpikir secara mendalam, berpikir kritis dilakukan secara sadar dan menggunakan intuisi yang tinggi. Mahasiswa menilai pikiran tentang kejelasan, ketepatan, ketelitian, relevansi, dan kelogisan secara intuitif. Mahasiswa yang mempunyai KPM sedang pada tingkatan beginning thinking dan practicing thinking. Pada tingkatan berpikir permulaan (beginning thinking), mahasiswa mulai memodifikasi beberapa kemampuan berpikirnya tetapi memiliki wawasan terbatas. Mahasiswa kurang memiliki perencanaan yang sistematis untuk meningkatkan kemampuan berpikirnya. Pada tingkatan berpikir latihan (practicing 
thinking), mahasiswa mampu menganalisis pemikirannya secara aktif dalam sejumlah bidang namun masih mempunyai wawasan terbatas dalam tingkatan berpikir yang mendalam. Mahasiswa yang mempunyai KPM rendah pada tingkatan unreflective thinking dan challenged thinking. Pada tingkatan berpikir yang tidak direfleksikan (unreflective thinking), mahasiswa tidak menyadari standar yang tepat untuk penilaian berpikir yaitu kejelasan, ketepatan, ketelitian, relevansi, kelogisan. Pada tingkatan berpikir yang menantang (challenged thinking), mahasiswa sadar peran berpikir dalam kehidupan, menyadari berpikir berkualitas membutuhkan berpikir reflektif yang disengaja, dan menyadari berpikir yang dilakukan sering kekurangan tetapi tidak dapat mengidentifikasikan dimana kekurangannya.

\section{KESIMPULAN DAN SARAN}

Berdasarkan hasil penelitian dan pembahasan, maka dapat disimpulkan:

1. Kemampuan pemecahan masalah merupakan tujuan umum pembelajaran matematika. Pemecahan masalah mengutamakan proses dan strategi yang dilakukan mahasiswa dalam menyelesaikan suatu permasalahan. Adanya suatu masalah dapat mendorong mahasiswa untuk dapat memecahkan masalah namun tidak tahu secara langsung bagaimana menyelesaikannya. Pemecahan masalah sangat penting dan membutuhkan berpikir tingkat tinggi (berpikir kritis), namun sebenarnya dapat dipelajari.

2. Ada lima tipe masalah yang digunakan dalam soal pemecahan masalah yaitu: simple translation problem, complex translation problem, process problem, applied problem, dan puzzle problem.

3. Profil berpikir kritis mahasiswa dalam memecahkan masalah matematika dasar menurut kriteria FRISCO pada setiap langkah pemecahan Polya sebagai berikut: a) Mahasiswa dengan KPM tinggi mengetahui fokus, alasan, situasi dan kejelasan dalam setiap tahap pemecahan masalah juga menjelaskan inferensinya pada setiap tahap pemecahan masalah Polya pada masalah penerjemahan sederhana, penerjemahan komplek, dan penerapan; b) Mahasiswa dengan KPM sedang, mengetahui fokus, alasan, situasi dan kejelasan dalam setiap tahap pemecahan masalah juga menjelaskan inferensinya pada setiap tahap pemecahan masalah Polya pada masalah penerjemahan sederhana dan masalah penerapan; dan c) Mahasiswa dengan KPM rendah, mengetahui fokus, alasan, inferensi, situasi, klarifikasi dan memeriksa kembali pada setiap langkah pemecahan masalah Polya pada masalah penerjemahan sederhana.

4. Tingkatan berpikir kritis mahasiswa yang mempunyai KPM tinggi adalah advanced thinking dan accomplished thinking, tingkatan berpikir kritis mahasiswa yang mempunyai KPM sedang adalah beginning thinking dan practicing thinking, sedangkan tingkatan berpikir kritis mahasiswa yang mempunyai KPM rendah adalah unreflective thinking dan challenged thinking.

Berdasarkan hasil penelitian dan pembahasan dapat disarankan bahwa untuk menumbuhkan pemikir kritis, maka sebaiknya pendidik (guru/ dosen) melatihkan kepada peserta didik (siswa/ mahasiswa) beberapa hal dalam pembelajaran yaitu: 1) mengungkapkan hal secara ringkas dan masuk akal; 2) menggunakan bukti yang kuat dan tidak memihak; 3) membedakan secara logis antara simpulan yang valid dan tidak 
valid; 4) menangguhkan penilaian, bila tidak ada bukti yang cukup untuk mendukung sebuah keputusan; 5) mengantisipasi kemungkinan konsekuensi dari suatu tindakan; 6) mencari kesamaan dan analogi (kemiripan); 7) mengakui kekurangan terhadap pendapatnya sendiri; dan 8) menerapkan teknik pemecahan masalah (problem solving).

\section{DAFTAR RUJUKAN}

Charles, Randall. (1982). Teaching Problem Solving: What, Why \& How. Dale Seymour Publications.

Elder, L., \& Paul, R. (2010). Critical Thinking Development: A Stage Theory with Implications for Instruction. http://www.criticalthinking.org/pages/critical-thinkingdevelopment-a-stage-theory $/ 483$

Ennis, Robert H. (1995). Critical Thinking. New Jersey: Prentice-Hall.

Fisher, Alec. (2001). Critical Thinking, An Introduction. Cambridge: Cambridge University Press.

Gega, Peter C. (1977). Science in Elementary Education. New York: John Wiley And Sons Inc.

Holmes, Emma E.(1995). New Directions in Elementary School Mathematics Interactive Teaching and Learning. New Yersey: A Simon and Schuster Company.

Johnson, Elaine B. (2007). Contextual Teaching and Learning Menjadikan Kegiatan Belajar-Mengajar Mengasyikkan dan Bermakna. Terjemahan Ibnu Setiawan. Bandung: Mizan Learning Center.

Krulik, S \& Rudnick, JA. (1989). Problem Solving: A Handbook for Teachers. Boston: Allyn and Bacon Inc

Lenchner, George. (1983). Creative Problem Solving in School Mathematics. New York: Glenwood Publication Inc.

Polya, G. (1973). How to Solve It: A New Aspect of Mathematical Method (2 ${ }^{\text {nd }}$ Edition). New Jersey: Princeton University Press.

Suherman, Erman. (2003). Strategi Pembelajaran Matematika Kontemporer. Bandung: JICA. 